\title{
CULTURAL AND DOMESTIC ARRANGEMENT OF MIGRANT KOLKHOZES AND THE DAILY LIFE OF SETTLERS IN THE NORTH CAUCASUS REGION IN THE PERIOD OF COLLECTIVIZATION
}

\author{
Vadim R. Istyagin \\ Rostov State Economic University, Rostov-on-Don, Russian Federation
}

\begin{abstract}
In the present article based on rare archival materials for the first time used in scientific circulation the author examines the issues of cultural and domestic arrangement of migrant kolkhozes (collective farms) in the North Caucasus region in the period of agriculture collectivization. The author highlights the key activities of regional authorities in the sphere of cultural development within these collective farms. It is stated that cultural arrangement of resettlement of collective farms in the 1930s was far from ideal. But taking into account state importance of the resettlement campaign, the authorities managed to achieve certain positive changes. An integral part of the cultural life of the people of the red army was its political and ideological component, due to the high level of politicization of public life in the USSR in 1930s. The red army collective farms were equipped with schools, nurseries and kindergartens, clubs and cinemas but these institutions were poorly organized. The article points out that labour of the red army settlers had little common features with farms of the local people. Community production activities and everyday leisure are, on the contrary, marked by the similarity of lifestyle. The mass spread of literacy stimulated the reader's interest - immigrants in their leisure hours read the newspapers, magazines and books, mainly fiction. The author examines the everyday life of immigrants, and it is largely substantiated by their social moods which contributed to the formation of the red army collective farms. The author came to the conclusion that the daily life of settlers was largely due to their social disadvantage. Food and accommodation, working conditions were at a very low level. For most of them, life and work in the Kuban Cossack villages was a daily test of their physical and moral forces and was not much different from the life of the Kuban collective farmers.
\end{abstract}

Key words: migration, migration policy, kolkhoz, collectivization, culture, daily routine, everyday life.

УДК 94(47).084.6

Дата поступления статьи: 25.01.2016

ББК (т)63.3(2)614

Дата принятия статьи: 20.05.2016

\section{КУЛЬТУРНО-БЫТОВОЕ ОБУСТРОЙСТВО ПЕРЕСЕЛЕНЧЕСКИХ КОЛХОЗОВ И ПОВСЕДНЕВНОСТЬ ПЕРЕСЕЛЕНЦЕВ В СЕВЕРО-КАВКАЗСКОМ КРАЕ В ПЕРИОД КОЛЛЕКТИВИЗАЦИИ}

\author{
Вадим Роланович Истягин \\ Ростовский государственный экономический университет, г. Ростов-на-Дону, Российская Федерация
}

\footnotetext{
Аннотация. В статье на основе опубликованных и впервые вводимых в научный оборот архивных материалов рассматриваются вопросы культурно-бытового обустройства переселенческих колхозов в Северо-Кавказском крае в период коллективизации сельского хозяйства. Раскрываются основные направления i. деятельности краевых властей в сфере культурного строительства в этих колхозах, масштабы создания в них культурно-просветительских учреждений. Анализируется повседневность переселенцев и во многом обусловленные ею их социальные настроения. Показано, что трудовая деятельность и досуг красноармейцевпереселенцев практически не имели своих особенностей в сравнении с колхозами, сформированными из местных жителей. Сформулированы выводы о том, что повседневность переселенцев была во многом обусловлена их общим неблагополучным социально-бытовым положением.
} 
Ключевые слова: переселение, переселенческая политика, колхоз, коллективизация, культура, быт, повседневность.

В современных реалиях миграционные процессы создают ряд проблем, которые требуют от государства активных действий по их решению. Переселенческая политика является составной частью стратегии экономического и социального развития страны. Государственное регулирование миграционных процессов в России представляет собой проблему, учитывающую целый комплекс факторов, включая масштабы территории, схему расселения, протяженность границ, особенности развития отдельных регионов, состояние рынка труда и многие другие. Все эти факторы обусловливают настоятельную потребность изучения имеющегося опыта организации государственного планового переселения и регулирования переселенческих потоков.

Одним из важных факторов организации колхозной системы являлась государственная переселенческая политика. Переселенческое движение было представлено в нескольких ипостасях: социальной, хозяйственной, политической и культурной, что дает основания трактовать его в качестве важнейшей составной части осуществления коллективизации, предопределившей специфику реализации аграрной политики на Юге РСФСР.

Целью данной статьи является рассмотрение одного из важных аспектов реализации переселенческой политики, а именно культурно-бытовое обустройство переселенческих колхозов и повседневности переселенцев в Северо-Кавказском крае в период коллективизации.

Отдельные вопросы данной темы получили определенное освещение в работах Н.И. Платунова [9], Н.С. Тарховой [16], А.П. Скорика и С.Д. Багдасарян [14]. В то же время объектом специального научного исследования данная проблема вплоть до настоящего времени не являлась.

Прибывшие на кубанскую землю в период коллективизации сельского хозяйства красноармейцы-переселенцы должны были не только добросовестно работать в колхозах и МТС и увеличивать объемы поставок сельскохозяйственной продукции государству. Они также должны были стать образцом зажиточного колхозника и воочию демон- стрировать преимущества жизни в коллективизированной станице. Но, поскольку сельская жизнь заключалась не только в работе на колхозных полях и фермах, немалое внимание власть уделяла культурному строительству и организации досуга переселенцев - молодых людей с семьями.

Неотъемлемой частью культурной жизни переселенцев-красноармейцев являлась ее политико-идеологическая составляющая, что объяснялось общим высоким уровнем политизации общественной жизни в СССР в 1930-е годы. Красноармейцы-переселенцы, будучи социальной опорой власти, обязаны были регулярно повышать уровень своей политической грамотности.

На протяжении 1920-х гг. в нэповскй деревне и станице Юга России было сделано немало для становления и развития различных форм культуры [14]. Но раскулачивание и выселение населения, голод 1932-1933 гг., депортация жителей «чернодосочных» станиц ${ }^{1}$ и разгул насилия в отношении селян отнюдь не способствовали развитию культурной жизни и улучшению состояния колхозных клубов и библиотек. В этой связи некоторые воинские части, направлявшие завербованных добровольцев в станицу Красноармейскую (бывшую «чернодосочную» станицу Полтавскую), снабжали их не только продуктами питания, но и столь необходимыми в разоренной станице предметами культпросвета: кинопередвижками, радиочемоданами, гармошками, пластинками, балалайками, мандолинами, шашками, домино, литературой и даже чистой бумагой для написания писем [16, с. 254]. Однако привезенного имущества было явно недостаточно для налаживания культурной жизни в новых красноармейских колхозах. Так, красноармейцы созданного в станице Красноармейской колхоза имени Балицкого в направленном в июне 1933 г. письме в штаб Северо-Кавказского военного округа сообщали о своей жизни. Отметив, что сумели навести хозяйственный порядок в колхозе и успешно провели посевную кампанию, авторы письма пожаловались на низкий культурный уровень в колхозе, порожденный дефицитом 
средств и царившей в станице разрухой. Они сетовали, что в ленинских уголках мало книг и нет радиоприемников, нет учебников для политпросвещения, отсутствуют музыкальные инструменты и спортивные снаряды [1, с. 203-204]. Некоторых холостых красноармейцев тянуло в город на стройки промышленных предприятий, они жаловались: «бурьяну на улицах много», «скучно, людей мало», «кино нет» и т. д. [9, с. 212]. Переселенец Петр Голиков из станицы Старовеличковской Тимашевского района в ноябре 1933 г. сообщал бывшим сослуживцам: «станица очень хорошая, вся в садах, выйдешь из дома - здесь сад и все удовольствия, но народу очень мало, веселья никакого нет» [7, л. 67]. Отсутствие элементарных способов проведения досуга и необустроенность клубов во многих станицах в совокупности с материально-бытовыми проблемами являлись вескими причинами обратничества, то есть возвращения прибывших добровольцев обратно на прежние места жизни. О необходимости развития в переселенческих станицах культуры говорилось в совместном постановлении бюро крайкома, президиума крайисполкома и политсектора МТС «О положении переселенцев-красноармейцев» от 1 октября 1934 года. Культурно-пропагандистскому отделу крайкома (культпроп) было поручено в декадный срок наметить конкретные мероприятия по оживлению культурной жизни в красноармейских колхозах: клубы, кружки, кино, радио [11, л. 14]. Краевая власть теперь обращала внимание на инициативы местного руководства в культурой сфере. 14 октября объединенное бюро крайкома и политсектора МТС рассматривало вопрос о положении переселенцев-красноармейцев в колхозах Динской и Роговской МТС. Начальнику политотдела Ново-Мышастовской МТС Октябрьскому было указано на явную незаконность его распоряжения о передаче музыкальных инструментов (гармони, балалаек, патефонов), полученных красноармейцами как подарок от своей воинской части, в сельскую читальню, где они были разбиты. Ему было предложено немедленно приобрести такие же инструменты и возвратить переселенцамкрасноармейцам $[12$, л. 8]. В конце октября крайком постановил: «Учитывая, что в ст[анице] Старо-Щербиновской, имеющей значи- тельный контингент красноармейцев-переселенцев, нет оборудованного колхозного клуба, разрешить райкому [и] РИКу деньги от проданной закрытой церкви использовать на оборудование межколхозного клуба» [12, л. 12 об.].

Развернутый перечень мероприятий по оживлению культурной жизни в красноармейских колхозах ${ }^{2}$ был утвержден крайкомом 18 ноября 1934 г. в ответ на упоминавшееся совместное постановление краевого руководства от 1 октября. В постановлении были введены три направления работы: «по линии политпросветработы и распространению печати», «по кино» и «по самодеятельному искусству». Крайком обязал краевой отдел народного образования (КрайОНО) развернуть по всем 60 кубанским станицам, в которых расположены красноармейские колхозы и бригады, сеть общеобразовательных школ для взрослых (начальных и повышенного типа) с таким расчетом, чтобы охватить учебой всех неграмотных и малограмотных членов красноармейских семей. Для красноармейских школ обеспечивались повышенные нормы обеспечения учебниками и учебными пособиями. Госкультснаб обязали в течение декады отгрузить по целевому назначению в красноармейские колхозы учебные пособия и принадлежности. КрайОНО (Баруличева) обязали командировать в красноармейские станицы 20 квалифицированных политпросветработников, обязав их в 2-декадный срок проверить работу политпросветучреждений, подобрать культработников и наладить политпросветработу. Согласно плану КрайОНО на 1934 г. опорные библиотеки были образованы только в 32 станицах, а потому крайком обязал КрайОНО с привлечением КрайЗУ, политсектора МТС и крайкома союза МТС обеспечить организацию опорных библиотек в остальных 28 станицах не позднее 15 ноября текущего года. Краевому библиоколлектору КОГИз, в свою очередь, надлежало обеспечить комплектование этих библиотек литературой. Крайкому союза МТС предложили принять на работу библиотекарей до конца 1934 года. Средства на комплектование библиотек «должны быть организованы» КрайОНО в соответствии с постановлением Наркоматов просвещения, земледелия, Политуправления МТС и ЦК союза МТС с привлечением дополнительных 


\section{ОТЕЧЕСТВЕННАЯ ИСТОРИЯ}

средств шефствующих над станицами предприятий. Крайком также обязал КрайОНО выделить из дополнительных ассигнований 30 тысяч рублей на пополнение нуждающихся в срочном комплектовании опорных библиотек в красноармейских станицах (Ленинградская и др.). Руководство КОГИЗ, Союзпечать и Крайпотребсоюз крайком обязал взять на усиленное снабжение литературой киоски при политотделах МТС в красноармейских станицах [10, л. 35-35 об.].

Если библиотеки были организованы в половине станиц с переселенцами, то ситуация с кинематографической сетью была значительно хуже. В станицах существовали «киностационары», но использовались далеко не по назначению. Крайком обязал Заготзерно немедленно освободить и отремонтировать занятые им киностационары в станицах Кущевской, Темижбекской, Тимашевской, Старо-Величковской и Ново-Рождественской, освободить и «привести в надлежащий вид» частично занятые помещения кинематографа в других станицах. Азчеркино (Семенов) поручили в 2-декадный срок совместно с местными организациями обеспечить электроэнергией бездействующие киностационары в станицах Поповической, Ладожской и Старо-Корсунской [10, л. 15 об.].

В плане работы самодеятельности крайком обязал управление театрально-зрелищных предприятий (УТЗП) КрайОНО (Полянский) организовать шефство театров над красноармейскими станицами ${ }^{3}$ по районам: Большой Ростовский театр - Кущевский, Ростовский ТРАМ (Театр рабочей молодежи) - Славянский, Ростовский ТЮ3 - Тимашевский, Таганрогский театр - Павловский, Ейский театр Ейский, Армавирский театр - Армавирский, Краснодарский театр - Краснодарский. На шефствующие театры была возложена организация "художественного обслуживания» подшефных станиц путем выделения художественных коллективов, организации новых художественно-самодеятельных кружков, инструктажа существующих и проведение краткосрочных (10-15 дней) курсов кружководов этих станиц. КрайОНО (Баруличева) обязали скомплектовать и выслать во все красноармейские станицы по одной библиотечке (пьесы, ноты, методические указания и др.) сто- имостью в среднем до 20 рублей за счет средств культфонда колхозов [10, л. 35-35 об.].

10 января 1935 г. бюро крайкома предложило райкомам с целью усиления массовой работы с красноармейцами-переселенцами и улучшения их культурно-бытового обслуживания прикрепить из числа районного партактива к каждому красноармейскому колхозу и бригаде одного ответственного. Крайком определил, что «прикрепленный товарищ» был обязан не менее одного раза в месяц лично бывать в подшефном колхозе или бригаде [13, л. 12]. Таким образом, краевое руководство наметило к реализации широкую программу оживления культурной жизни в переселенческих станицах и определило ответственных за проведение этой работы.

Однако реальная ситуация с культурной жизнью в станицах была далекой от идеала. Из колхоза имени Менжинского станицы Пластуновской Кореновского района весной 1934 г. сообщалось: «...очень плохо с культобслуживанием бригад, за все время не было ни одной кинопостановки» [4, л. 24].

Проведенная в конце 1934 г. крайисполкомом и крайкомом партии проверка положения дел в сфере культурного развития в отдельных красноармейских колхозах Черноморья выявила, что работа эта находилась на «недопустимо низком уровне» [2, л. 24]. В составленной по итогам данной проверки докладной записке заместителя начальника краевого земельного управления Лучанинова секретарю крайкома ВКП (б) Малинову «О состоянии партийно-массовой работы в переселенческих красноармейских колхозах Черноморья» отмечалось, что в колхозах совершенно недостаточна база для организации культурной работы: не пополнялись библиотеки, плохо или совсем не работали радиоточки, не устраивались читки газет. Вывод доклада был неутешительным: «отсутствие организованного культурного развлечения, увязки его с производственными задачами, стоящими перед колхозами», вело в отдельных колхозах к ослаблению трудовой дисциплины, к пьянкам среди красноармейского состава, хотя и стоявшего на более высокой ступени культурного развития, чем старожильский состав [2, л. 24-25].

Значительные проблемы существовали и в плане бытового обустройства переселен- 
цев и их продовольственного снабжения. Так, в конце года на трудодни колхозникам-переселенцам выдавали натуральную оплату продуктами питания. Но по причине скудного материально-бытового снабжения они были вынуждены приобретать за собственные средства одежду и обувь, продавая часть полученных продуктов. В колхозе имени Ворошилова Советской МТС Армавирского района красноармейцы осенью 1933 г. получили на трудодень овощи, мед, деньги и по 13 кг зерна [17, с. 550-551]. В 1934 г. колхозникам колхоза имени Балицкого Славянского района было выдано на трудодень по 7 кг муки, всего предполагалось выдать по 12-13 кг, из них муки - по 10 кг. Из полученной на трудодни муки к середине сентября 1934 г. колхозники продали кооперации около 30 т и полученные деньги «обращают на заказ одежды и обуви и велосипедов» [3, л. 32].

А как оценивали свою жизнь на новом месте сами переселенцы? Реалии повседневной жизни на новом месте переселенцы излагали в письмах, в которых откровенно и без оглядки на колхозное начальство описывали свою жизнь. Некоторые были довольны новым местом жительства и с удовлетворением сообщали об этом в своих письмах. Один из безвестных переселенцев был полон решимости: «Чувствую, что в работе произошел большой перелом. Работал ведь я и до армии, но теперь появилась какая-то решительность, самоуверенность в начатом деле, в его победе и твердости, которой не хватало. Красная армия на 100 процентов ворочает человека» [8, с. 117]. Армейские политработники использовали подобные отзывы для приукрашивания истинной картины социально-бытового устройства переселенцев. Тем не менее среди переселенцев действительно были люди, искренне приветствовавшие свое переселение на кубанскую землю и с оптимизмом смотревшие на работу в созданных красноармейских колхозах. Сложно определить, какая часть переселенцев высказывала положительные отзывы о жизни на кубанских станицах, но таковые, безусловно, были.

Но для большинства переселенцев условия повседневной жизни были не такими идеальными. Автору удалось обнаружить несколько опубликованных писем красноармей- цев. Так, в письме бывшего красноармейца Исупова военкому 32-го стрелкового полка от 8 апреля 1933 г. говорилось: «Во-первых, хочу Вам передать большевистский привет, а дальше сообщу, как мы в настоящее время живем. Живем очень плохо, почти по суткам живем голодные. Сейчас сеем, сеять не на ком, лошадей в бригаде 17, посеяли 60 га, лошади стали, не ходят, приходится пахать и сеять на людской силе. Хлеба дают, что корм, 400 г на день. Эх, знал бы, что я помру здесь от голода и скоро, то покончил бы сам себя. За что нас сюда выгнали... Но мы до осени как-нибудь прожили бы, но наши-то семьи за что здесь погибают, едят хлеба 200 г, а хлеб мы Вам пошлем в посылке на пробу, наверно, наши бы свиньи в части не стали бы есть. Я определенно заявляю, пущай судят, живу только до осени, только если останусь жив. Вот какая нам пришла жизнь, что от голода десятки помирают каждый день» [6, с. 473].

Второе письмо бывшего красноармейца В.Г. Шустикова из колхоза имени Шеболдаева станицы Уманской Павловского района Северо-Кавказского края бывшему командиру от 11 марта 1933 г.: «Так вот, товарищ Васев. Зачем меня завербовали... Вы говорили, что там будет очень хорошо жить, но это все неправда. Я живу в настоящее время очень плохо, так плохо, что в жизни не встречался с таким положением. Кормят нас совсем плохо... Продукты совершенно ничего не дают, еле-еле уже ноги таскаем, работать очень здорово придется. Работать-то бы мы работаем, но кое-как ноги таскаем. Очень уж много народу обратно убежали отсюда, потому что невозможно жить, и еще много, наверное, удерут» [6, с. 474].

Следует подчеркнуть, что подобная картина переселенческой повседневности наблюдалась не только в «чернодосочных» станицах, но и остальных кубанских районах и станицах. Красноречиво описал свое житье переселившийся в октябре 1933 г. в Тихорецкий район бывший красноармеец 111-го артиллерийского полка (Ленинградский военный округ) С.П. Телегин в письме на имя военкома полка: «Теперь я хочу коснуться личной жизни. Живем мы в одной квартире 4 чел. - Суворов, Комельков, Дударев и я. Спим на голых нарах, постельных принадлежностей нет, стола нет, ламп нет, скамеек нет, пища очень 
скверная, больше всего капуста и фасоль...» $[15$, c. 271$]$.

Объективные сведения об устройстве и жизни переселенцев на новом месте содержатся в предназначавшемся руководству Всероссийского переселенческого комитета докладе местного руководства ОГПУ об итогах переселения. В декабре 1933 г. чекисты констатировали, что уже с прибытием первых эшелонов с переселенцами в станицы выявился целый ряд «организационных неполадок», вызвавших недовольство и отрицательные настроения красноармейцев [5, л. 18]. В целом повседневный быт и условия труда переселенцев были на крайне низком уровне: «для переселенческих бригад в поле не были организованы стоянки, допускались случаи уравниловки в питании, качество питания было низкое, имели место грубые обращения с переселенцами, расходование не по назначению кредитов, отпущенных для переселенцев и т. п.» [5, л. 19].

Побывавший в командировке на Кубани сотрудник газеты «Правда» А. Дунаевский в феврале 1934 г. в письме главному редактору газеты Л.З. Мехлису изображал типичную картину жизни переселенческой семьи: «Приходишь в хату красноармейской семьи. Их 68 человек, на всех 1-2 стула и 1 кровать, нет даже стола. Вечером сидят без света, ибо кооперация отказывается снабжать керосином. Надо было отремонтировать хаты, но предназначенные для красноармейцев стройматериалы Усть-Лабинский райисполком израсходовал на свои нужды» [3, с. 355].

Среди переселенцев имели место различные социальные девиации, наиболее частыми были пьянство и драки. В декабре 1933 г. в спецсообщении ОГПУ отмечалось, что имевшиеся недочеты в хозяйственно-бытовом устройстве, а также агитация «к. р. элемента» отрицательно влияет на наименее устойчивую часть переселенцев. За последнее время отмечались случаи «антиморальных проявлений»: пьянство и дебоши [15, с. 265]. В станицах Темижбекской Кропоткинского района и Величковской Тимашевского района было отмечено 3 случая «групповых пьянок» красноармейцев, причем в Темижбекской 2 «пьянки» сопровождались драками с применением ножей [5, л. 21].

Таким образом, культурно-бытовое обустройство переселенческих колхозов в 1930-е гг. было далеким от идеала. Но принимая во внимание государственное значение переселенческой кампании, удалось добиться определенных позитивных сдвигов. В красноармейских колхозах были открыты и оборудованы школы, ясли и детские сады, имелись клубы, а кое-где и кинотеатры, однако обеспечены они были крайне скудно. И если школы и детские сады работали, то учреждения культуры и досуга - библиотеки, клубы, кинотеатры - из-за плохой организации их работы и просто нерадивого отношения к своей деятельности их сотрудников, часто бездействовали. В библиотеках имелись газеты, журналы и книги, но грамотность, особенно среди женщин, была низкой. Краевое руководство придавало серьезное значение всемерному развитию культуры в колхозах, принимало решение о развитии трех направлений культуры: политпросветработы и печати, кинематографа и самодеятельного искусства (театра). Наибольшие успехи были достигнуты в развитии сети колхозных библиотек. Трудовая повседневность и досуг красноармейцев-переселенцев практически не имели своей особенности в сравнении с колхозами, сформированными из местных жителей.

Общность производственной деятельности и повседневного досуга предопределила схожесть образа жизни. Переселенцы, как и все колхозники, в 1930-е гг. жили весьма скудно, хотя и стремились приобрести одежду и обувь, некоторые даже имели предмет роскоши - велосипед, что являлось признаком известной зажиточности. Массовое распространение грамотности стимулировало читательский интерес - переселенцы в часы досуга читали газеты, журналы и книги, главным образом беллетристику. Основным источником получения книжной печатной продукции являлись, естественно, колхозные библиотеки. Периодическую печать либо брали там же, либо приобретали самостоятельно. Слушали радио, если оно имелось и работало, смотрели кинокартины. Особенностью культурной жизни для переселенцев стало их участие в школах партпросветучебы. Впрочем, далеко не все красноармейцы демонстрировали успехи в изучении сочинений большевистских вождей, резолюций партийных съездов и пленумов, о чем с сожалением отмечали местные парторги. 
Неудовлетворительное состояние местной культуры часто становилось причиной распространения социальных девиаций, традиционных для деревни форм проведения «досуга»среди красноармейцев фиксировались случаи пьянства, как следствие снижалась трудовая дисциплина. Не способствовали развитию культуры объективные трудности становления красноармейских колхозов. Повседневность переселенцев была во многом обусловлена их социально-бытовым неблагополучием. Жилье и питание переселенческих семей, условия труда не выдерживали никакой критики и были на крайне низком уровне.

\section{ПРИМЕЧАНИЯ}

1 «Чернодосочные» станицы - условное название 13 кубанских и 2 донских станиц, не выполнивших явно нереальные планы сдачи хлеба государству и занесенных в специальные списки на доску с последующей их полной блокадой силовыми средствами, вследствие чего их жители либо физически вымирали, либо насильственно выселялись в отдаленные необжитые районы на Севере и в Сибири.

2 Красноармейские колхозы - колхозы, образованные из прибывших переселенцев - демобилизованных красноармейцев.

3 Красноармейские станицы - бывшие «чернодосочные» станицы, заселенные переселенцамикрасноармейцами.

\section{СПИСОК ЛИТЕРАТУРЫ}

1. Бочарова, О. В. Формирование и деятельность политических отделов МТС в казачье-крестьянских районах Юга России : дис. ... канд. ист. наук / Бочарова Ольга Владимировна. - Новочеркасск, 2015. -278 c.

2. Докладная записка заместителя начальника краевого земельного управления Лучанинова секретарю крайкома ВКП(б) Малинову о состоянии партийно-массовой работы в переселенческих красноармейских колхозах Черноморья, б/д // Центр документации новейшей истории Ростовской области (далее - ЦДНИРО). - Ф. 8. - Оп. 1. - Д. 112.

3. Докладная записка инструктора сельхозотдела М.И. Судьбина секретарю крайкома ВКП(б) Малинову по вопросу о результатах проверки первичной парторганизации колхоза им. Балицкого Славянского района, б/д // ЦДНИРО. Ф. 8. - Оп. 1. - Д. 61.
4. Доклад секретаря парткома колхоза им. Менжинского станицы Пластуновской Кореновского района Азово-Черноморского края С. Сурба в сельхозотдел крайкома ВКП(б) Золотареву, б/д // ЦДНИРО. Ф. 8. - Оп. 1.- Д. 43.

5. Доклад секретно-политического отдела Полномочного представительства ОГПУ по Северо-Кавказскому краю и Дагестанской ССР «Об итогах переселения красноармейских хозяйств в Северо-Кавказский край (октябрь-декабрь 1933 г.)» // Российский государственный архив экономики. Ф. 5675. - Оп. 1. - Д. 43.

6. Донесение начальника политотдела 11-й стрелковой дивизии Гладышева начальнику Политуправления Ленинградского военного округа И.Е. Славину о продовольственных затруднениях в стан. Уманской Северо-Кавказского края, 29 апреля 1933 г. // Голод в СССР. 1929-1934. Документы. В 3 т. Т.2 : Июль 1932 - июль 1933 г. - М. : МДФ, 2012. $-1116 \mathrm{c}$.

7. Копии писем красноармейцев-переселенцев из Приволжского военного округа, направленные начальником Главного управления РККА Фельдманом командующему войсками СКВО, и в копии секретарю Азово-Черноморского крайкома ВКП(б) Шеболдаеву, 25 января 1934 г. // ЦДНИРО. Ф. 8. - Оп. 1. - Д. 25.

8. Очевидцы рассказывают // Родная Кубань. - 2002. - № 3 .

9. Платунов, Н. И. Переселенческая политика советского государства и ее осуществление в СССР (1917 - июнь 1941 г.) / Н. И. Платунов. - Томск : Издво Том. ун-та, 1976. - 381 с.

10. Постановление бюро Азово-Черноморского крайкома ВКП(б) от 22 ноября 1934 г. «О мероприятиях по оживлению культурной жизни в красноармейских колхозах» // ЦДНИРО.-Ф. 8.-Оп. 1.-Д. 63.

11. Протокол № 28 заседания бюро Азово-Черноморского крайкома ВКП(б) от 2 октября 1934 г. Объединенное решение бюро крайкома, президиума крайисполкома и политсектора МТС «О положении переселенцев-красноармейцев» // ЦДНИРО. Ф. 8. - ОП. 1. - Д. 58.

12. Протокол № 30 заседания бюро АзовоЧерноморского крайкома ВКП(б) от 23 октября 1934 г. // ЦДНИРО. - Ф. 8. - Оп. 1. - Д. 60.

13. Протокол № 37 заседания бюро Азово-Черноморского крайкома ВКП(б) от 10 февраля 1935 г. // ЦДНИРО. - Ф. 8. - Оп. 1. - Д. 110.

14. Скорик, А. П. Крестьянская повседневность эпохи нэпа: досуг и праздник в южно-российской деревне в 1920-е годы / А. П.Скорик, С. Д. Багдасарян. - Новочеркасск : Лик, 2012. - 239 с.

15. Спецсообщение секретно-политического отдела ОГПУ СССР «О ходе вселения красноармейских хозяйств в Северо-Кавказский край», 3 декаб- 
ря 1933 г. ; Спецсообщение Особого отдела ОГПУ $\mathrm{CCCP}$ «О недочетах в ходе переселения в колхозы Северо-Кавказского края демобилизованных красноармейцев и их семей», 13 декабря 1933 г. ; Письмо сотрудника газеты «Правда» А. Дунаевского главному редактору «Правды» Л.3. Мехлису о командировке на Кубань, не позднее 24 февраля 1934 г. // Голод в СССР. 1929-1934. Документы. В 3 т. Т. 3 : Лето 1933-1934 гг.-М. : МДФ, 2013. - 960 с.

16. Тархова, Н. С. Красная армия и сталинская коллективизация. 1928-1933 гг. / Н. С. Тархова. - М. : Российская политическая энциклопедия, 2010. - 375 с.

17. Характеристика колхозов им. Левандовского Наурской МТС и им. Ворошилова Советской МТС для рассмотрения вопроса о занесении их на Всесоюзную красную доску, 9 октября 1933 г. // Коллективизация сельского хозяйства на Северном Кавказе (1927-1937 гг.). - Краснодар : Книжное издательство, 1972. -824 с.

\section{REFERENCES}

1. Bocharova O.V. Formirovanie i deyatelnost politicheskikh otdelov MTS v kazachye-krestyanskikh rayonakh Yuga Rossii: dis. ... kand. ist. nauk [Formation and Activity of Political Departments of the MTS in the Cossack-Peasant Regions of the Southern Russia. Cand. hist. sci.]. Novocherkassk, 2015. 278 p.

2. Dokladnaya zapiska zamestitelya nachalnika kraevogo zemelnogo upravleniya Luchaninova sekretaryu kraykoma VKP(b) Malinovu o sostoyanii partiyno-massovoy raboty $\mathrm{v}$ pereselencheskikh krasnoarmeyskikh kolkhozakh Chernomorya [A Report of Deputy Chief of the Regional Land Management Luchaninov to Secretary of the Regional Committee of the CPSU (b) Malinov on the State of the Party and Mass Work in the Red Army Resettlement Farms of the Black Sea]. Tsentr dokumentatsii noveyshey istorii Rostovskoy oblasti [Centre of Documentation of the Modern History of the Rostov Region], F. 8, Op. 1, D. 112.

3. Dokladnaya zapiska instruktora selkhozotdela M.I. Sudbina sekretaryu kraykoma VKP(b) Malinovu po voprosu o rezultatakh proverki pervichnoy partorganizatsii kolkhoza im. Balitskogo Slavyanskogo rayona [Memorandum of Agro Department Instructor M.I. Sudbin to Secretary of the Regional Committee of the CPSU (b) Malinov on the Results of the Audit of the Primary Party Organization of Collective Farm. Balitsky Slavic Area]. Tsentr dokumentatsii noveyshey istorii Rostovskoy oblasti [Centre of Documentation of the Modern History of the Rostov Region], F. 8. Op. 1. D. 61 .

4. Doklad sekretarya partkoma kolkhoza im. Menzhinskogo stanitsy Plastunovskoy Korenovskogo rayona Azovo-Chernomorskogo kraya S. Surba v selkhozotdel kraykoma VKP(b) Zolotarevu [Report of the Secretary of the Party Committee of the Kolkhoz Named After Menzhinsky of Plastunovskaya Village of the Korenovsky District of Azov-Black Sea Region S. Surba to Agro Department of Regional Committee of the CPSU (b) Zolotarev]. Tsentr dokumentatsii noveyshey istorii Rostovskoy oblasti [Centre of Documentation of the Modern History of the Rostov Region], F. 8, Op. 1, D. 43.

5. Doklad sekretno-politicheskogo otdela Polnomochnogo predstavitelstva OGPU po SeveroKavkazskomu krayu i Dagestanskoy SSR “Ob itogakh pereseleniya krasnoarmeyskikh khozyaystv v SeveroKavkazskiy kray (oktyabr-dekabr 1933 g.)" [Report of the Secret Political Department of the OGPU Plenipotentiary Representative in the North Caucasus Territory and Dagestan SSR "On the Results of Migrating Farms in the Red Army of the North Caucasus Territory (October-December 1933)"]. Rossiyskiy gosudarstvennyy arkhiv ekonomiki [Russian StateArchive ofEconomy], F. 5675, Op. 1, D. 3.

6. Donesenienachalnika politotdela 11-y strelkovoy divizii Gladysheva nachalniku Politupravleniya Leningradskogo voennogo okruga I.E. Slavinu o prodovolstvennykh zatrudneniyakh v stan. Umanskoy Severo-Kavkazskogo kraya, 29 aprelya 1933 g. [Report by Chief of Political Department of the 11th Infantry Division Gladyshev to Chief of the Political Administration of the Leningrad Military District I.E. Slavin About Food Difficulties in the Umanskaya Village of the North Caucasus region, April 29, 1933]. Golod v SSSR. 1929-1934. Dokumenty. V 3 t. T.2: Iyul 1932-iyul 1933 g. [The Famine in the USSR. 1929-1934. Documents. In 3 vols. Vol. 2. July 1932-July 1933]. Moscow, MDF Publ., 2012. 1116p.

7. Kopii pisem krasnoarmeytsev-pereselentsev iz Privolzhskogo voennogo okruga, napravlennye nachalnikom Glavnogo upravleniya RKKA Feldmanom komanduyushchemu voyskami SKVO, i v kopii sekretaryu Azovo-Chernomorskogo kraykoma VKP(b) Sheboldaevu, 25 yanvarya 1934 g. [Copies of Letters of Red Army-Settlers From the Volga Military District, Directed by Chief of the Red Army Feldman Commanding the North Caucasus Military District, With a Copy to Secretary of Azov-Black Sea Territorial Committee of the CPSU (b) Sheboldaev, January 25, 1934]. Tsentr dokumentatsii noveyshey istorii Rostovskoy oblasti [Centre of Documentation of the Modern History of the Rostov Region], F. 8, Op. 1, D. 25.

8. Ochevidtsy rasskazyvayut [Witnesses Tell]. Rodnaya Kuban, 2002, no. 3.

9. Platunov N.I. Pereselencheskaya politika sovetskogo gosudarstva i ee osushchestvlenie v SSSR (1917-iyun 1941 g.) [Migration Policy of the Soviet State and Its Implementation in the USSR (1917June 1941)]. Tomsk, Izd-vo Tom. un-ta, 1976. 381 p.

10. Postanovlenie byuro Azovo-Chernomorskogo kraykoma VKP(b) ot 22 noyabrya $1934 \mathrm{~g}$. 
"O meropriyatiyah po ozhivleniyu kulturnoy zhizni v krasnoarmeyskikh kolkhozakh" [Regulation Bureau of Azov-Black Sea Territorial Committee of the CPSU (b) on November 22, 1934 "On Measures of Reviving the Cultural Life of the Red Army in the Collective Farms"]. Tsentr dokumentatsii noveyshey istorii Rostovskoy oblasti [Centre of Documentation of the Modern History of the Rostov Region], F. 8, Op. 1, D. 63.

11. Protokol № 28 zasedaniya byuro AzovoChernomorskogo kraykoma VKP(b) ot 2 oktyabrya 1934 g. Obyedinennoe reshenie byuro kraykoma, prezidiuma krayispolkoma i politsektora MTS "O polozhenii pereselentsev-krasnoarmeytsev" [Minutes no. 28 of Meeting of the Bureau of the Azov-Black Sea Territorial Committee of the CPSU (b) of October 2, 1934 Joint Regional Committee Bureau Decision, the Presidium of the Regional Executive Committee and Political Sector MTS "On the Situation of the Red ArmyMigrants"]. Tsentr dokumentatsii noveyshey istorii Rostovskoy oblasti [Centre of Documentation of the Modern History of the Rostov Region], F. 8, Op. 1, D. 58.

12. Protokol № 30 zasedaniya byuro AzovoChernomorskogo kraykoma VKP(b) ot 23 oktyabrya 1934 g. [Minutes № 30 of Meeting of the Bureau of the Azov-Black Sea Territorial Committee of the CPSU (b) on October 23, 1934]. Tsentr dokumentatsii noveyshey istorii Rostovskoy oblasti [Centre of Documentation of the Modern History of the Rostov Region], F. 8, Op. 1, D. 60.

13. Protokol № 37 zasedaniya byuro AzovoChernomorskogo kraykoma VKP(b) ot 10 fevralya 1935 g. [Minutes no. 37 meeting of the Bureau of the Azov-Black Sea Territorial Committee of the CPSU (b) on February 10, 1935]. Tsentr dokumentatsii noveyshey istorii Rostovskoy oblasti [Centre of Documentation of the Modern History of the Rostov Region], F. 8, Op. 1, D. 110.

14. Skorik A.P., Bagdasaryan S.D. Krestyanskaya povsednevnost epokhi nepa: dosug i prazdnik v yuzhno-rossiyskoy derevne v 1920-e gody [Peasant Everyday Life of the Era of NEP: Leisure and Holiday in the South Russian Village in 1920s]. Novocherkassk, Lik Publ., 2012. 239 p.
15. Spetssoobshchenie sekretno-politicheskogo otdela OGPU SSSR “O khode vseleniya krasnoarmeyskikh khozyaystv v Severo-Kavkazskiy kray", 3 dekabrya 1933 g.; Spetssoobshchenie Osobogo otdela OGPU SSSR "O nedochetakh v khode pereseleniya v kolkhozy Severo-Kavkazskogo kraya demobilizovannykh krasnoarmeytsev i ikh semey", 13 dekabrya 1933 g.; Pismo sotrudnika gazety "Pravda" A. Dunaevskogo glavnomu redaktoru "Pravdy" L.Z. Mekhlisu o komandirovke na Kuban, ne pozdnee 24 fevralya 1934 g. [Special Report of Secret-Political Department of the OGPU of the USSR "On the Red Army During the Introduction of Red Army Farms in the North Caucasus region", December 3, 1933; Special Report of the Special Section of the OGPU of the USSR "On the Shortcomings in the Resettlement Farms in the North Caucasus Region of Demobilized Soldiers and Their Families", December 13, 1933; Letter of A. Dunayevskiy, Employee of the Pravda Newspaper to Chief Editor L.Z. Mekhlis on the Trip to the Kuban Region, No Later Than February 24, 1934]. Golod v SSSR. 1929-1934. Dokumenty. V 3 t. T. 3: Leto 1933$1934 \mathrm{gg}$. [The Famine in the USSR. 1929-1934. Documents. In 3 vols. Vol. 3. Summer 1933-1934]. Moscow, MDF Publ., 2013.960 p.

16. Tarkhova N.S. Krasnaya armiya i stalinskaya kollektivizatsiya. 1928-1933 gg. [The Red Army and Stalin's Collectivization]. 1928-1933]. Moscow, Rossiyskaya politicheskaya entsiklopediya Publ., 2010.375 p.

17. Kharakteristika kolkhozov im. Levandovskogo Naurskoy MTS i im. Voroshilova Sovetskoy MTS dlya rassmotreniya voprosa o zanesenii ikh na Vsesoyuznuyu krasnuyu dosku, 9 oktyabrya 1933 g. [Characteristics of the Collective Farms named after Levandovski Naur MTS and after Voroshilov Soviet MTS to Address the Issue on Including Them in the Red-Union Board, October 9, 1933]. Kollektivizatsiya selskogo khozyaystva na Severnom Kavkaze (1927-1937 gg.) [The Collectivization of Agriculture in the North Caucasus (1927-1937 gg.)]. Krasnodar, Knizhnoe izdatelstvo, $1972.824 \mathrm{p}$.

\section{Information About the Author}

Vadim R. Istyagin, Postgraduate Student, Department of Historical Sciences and Political Science, Rostov State Economic University, M. Gorkogo St., 166, 344000 Rostov-on-Don, Russian Federation, vadim-chitchiyan@rambler.ru.

\section{Информация об авторе}

Вадим Роланович Истягин, аспирант кафедры исторических наук и политологии, Ростовский государственный экономический университет (РИНХ), ул. М. Горького, 166, 344000 г. Ростов-на-Дону, Российская Федерация, vadim-chitchiyan@rambler.ru. 